\title{
The Impact of EL-NIÑO/Southern Oscillation (ENSO) on Fishery and Water Quality in Lake Kinneret (Israel)
}

\author{
Moshe Gophen Migal \\ Scientific Research Institute, Kiryat Shmone, Israel \\ Email: Gophen@Migal.Org.il \\ Received 15 January 2016; accepted 3 April 2016; published 6 April 2016 \\ Copyright (C) 2016 by author and Scientific Research Publishing Inc. \\ This work is licensed under the Creative Commons Attribution International License (CC BY). \\ http://creativecommons.org/licenses/by/4.0/ \\ (c) (i) Open Access
}

\begin{abstract}
A correlation between fishery and extreme winter conditions in Lake Kinneret was indicated: populations of Bleak fishes were enhanced and those of Sarotherodon galilaeus (SG) declined. The aim of the present study is to confirm the relation of those correlations to EL-NINO/Southern Oscillation and its impact on Kinneret fishery. The study is based on long-term data records of the Kinneret Epilimnetic temperatures, water level increase, precipitation and air temperatures in the drainage basin, together with a record of EL NIÑO/Southern Oscillation (ENSO) events. Results suggest a confirmation of the impact of ENSO events on lake population size of Bleaks and SG. It is likely that the influence of ENSO on the two key fish species in the Lake is contradictory: enhancement of reproduction of the winter spawner Bleaks and reduction of population recruitment of the early summer spawner, Sarotherodon galilaeus. It is likely that winter extreme in Kinneret region is a consequence of ENSO event and therefore negatively affecting Kinneret water quality.
\end{abstract}

\section{Keywords}

Bleak, Sarotherodon galilaeus, Fishery, ENSO, Lake Kinneret

\section{Introduction}

Lake Kinneretr is the only natural freshwater lake in Israel. The lake is located below sea level at the northern part of the Syrian-African, Great Rift Valley. Since the year 1964 (the first year of the operation of the National Water Carrier), till date, the lake has been the major source for domestic (drinking) water supply (200 - 350 $\mathrm{mcm} /$ year, $10^{6} \mathrm{~m}^{3}$ annually) in the country. From early 2010, a major source of domestic water $(700 \mathrm{mcm})$ is from desalinization plants. Lake Kinneret is also used for commercial fisheries, recreation and tourism. In the 
last 20 years, the Kinneret ecosystem structure has undergone significant modifications. The major change was a turnaround of nutrient availabilities from Phosphorus to Nitrogen limitation within the biotic compartments of the ecosystem [1]. The algal dominance of the bloom, forming Pyrrhophyte Peridinium, was replaced with Cyanobacteria, and the fish food resources were modified, respectively. Independently, other external, natural and anthropogenic constraints created an additional pressure on the fishery: population increase of the migratory fish predator, Great Cormorant (Phalacrocorax carbo) in the lake, reduction in stocked fingerlings of the cichlid, Sarotherodon galilaeus (SG), the use of illegal small mesh sized fishing nets, the elimination of Bleaks fishing, and the outburst of Virus disease, which mostly infected Tilapias. It is most likely that the climatic conditions also resulted in fluctuations of the population size as well as that of SG. SG is a species of fish on top priority in the fishery management design, and it is aimed at water quality protection and fisher's income. During the year 2007-2008, landings of S. galilaeus sharply declined from an earlier amount of 200 - 400 tons annually to less than 10 tons in the year 2008 [1]. Among several other potential reasons for the decline of SG landings, the relevance of climatic conditions periodicity was also considered. In this paper, the analysis of correlation between SG fishery and the periodical impact of EL-NINO/Southern Oscillation Index (ENSO) was presented.

\section{Material and Methods}

The Long-Term Data record of Fishery in Lake Kinneret was taken from the Annual Reports [2] and [3]; The Limnological (Biota and Temperatures) data is given in the Annual (1969-2014) Reports from the Kinneret Limnological Laboratory, IOLR [4]. The periodicity Long-Term documented Information of the ENSO is published by NOAA Climate Prediction Center [5]; The Rain gauge and the air temperature data is given in the Israeli Meteorological Service [6] annual reports. Precipitation data in Kfar Giladi station (1926-2015) was synchronized by M. Inbar from the Berut record (1877-1926). Three statistical analyses were used: ANOVA Test ( $p$ $<0.05$ ); Value Prediction by Polynomial Fractional; and LOWESS (0.8), for trend indication [7].

\section{Results}

Some similarities were observed between the climatological parameters of daily minimal temperature, the precipitation record in the Hula Valley and the Water Level fluctuations in Lake Kinneret. During the period of 1877-2014 (129 years) of the precipitation record in KG station, 51 years were above the total average of 752 $\mathrm{mm} / \mathrm{y}(\mathrm{SD}=193 \mathrm{~mm} / \mathrm{y})$, of which there was 17 heaviest rainy years, with record of mean plus 1SD (=752 + 193 $=945 \mathrm{~mm} / \mathrm{y}$ ), an average of once per 3 years; 47 years of air temperature record, of which 14 years have a total mean minimal temperature below $13^{\circ} \mathrm{C}$, that is, once per 3.4 years; 91 years record of WL measurement in Lake Kinneret has shown an increase in winter months $(12,1-5)$ of more than the multiannual average of $16 \mathrm{~cm} / \mathrm{m}$ within 23 years, that is, an average of once per 3.9 years. These frequency values are close enough to suggest one parameter of mutual impact. It is assumed that ENSO phenomenon is responsible for the similarity that exists in the periodical performance of the climatic conditions in Lake Kinneret and its drainage basin. The results given in Table 1 emphasize the close relationship that exists between ENSO case and climatic conditions in Lake Kinneret. The decline of the SG and the increase of Sardine landings, as related to precipitation elevation,

Table 1. Cyclic timing of ENSO case [5] and WL increase in Lake Kinneret, as well as air temperature in the Kinneret drainage basin [4]-[6].

\begin{tabular}{ccc}
\hline Tem. min. $>11.9^{\circ} \mathrm{C}$ below average & Winter $\mathrm{WL}$ up $>20 \mathrm{~cm} / \mathbf{m o n t h}^{-}$ & Years of strong EL-NINO \\
\hline 12.5 & 23 & 1971 \\
$12.2,12.5$ & 25,25 & $1976-78$ \\
12.6 & 31 & 1980 \\
11.9 & 31 & 1983 \\
$11.9,12.5$ & 24,29 & $1986-88$ \\
$12.3,14.6$ & 32,38 & $1991-2$ \\
13.3 & 21 & 1994 \\
$12.1,12.8$ & 20,20 & $1997-98$ \\
$13.1,13.3$ & 23,76 & $2002-3$ \\
\hline
\end{tabular}


are presented in Figure 1 and Figure 2. An increase in precipitation reflects the ENSO`s impact (Price et al 1998). Consequently, it is suggested that the severity of winter conditions positively affects the Sardine population, and the opposite for SG, with a negative response.

Results in Figure 3 present the annual (1877-2014) precipitation record in most northern stations in the Kinneret Drainage Basin, Kfar Giladi with the extension of synchronized data from the Beirut record (1877-1926). The multi-annual average is $752 \mathrm{~mm} / \mathrm{y}$. The heavier precipitations during the year 1926-1927, are prominent
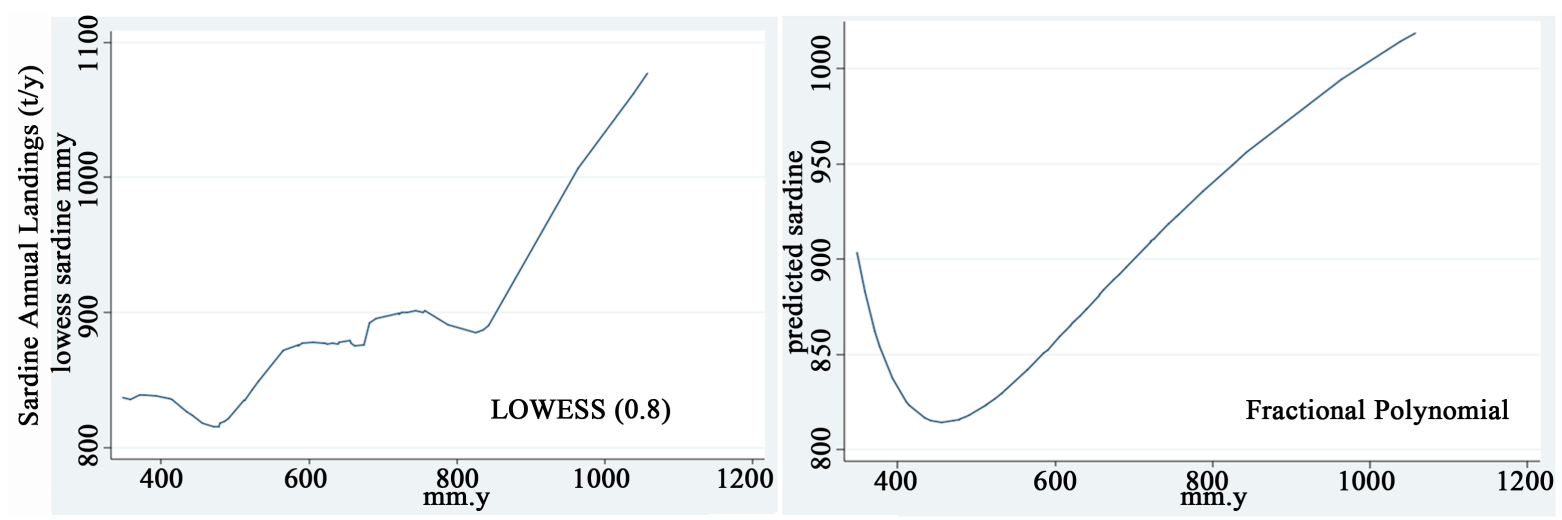

Figure 1. Annual landings ( $\mathrm{t} / \mathrm{y})$ of sardines in Lake Kinneret vs annual rain gauge (mm/y) given in two statistical analysis methods: LOWESS (trend of changes) and Fractional Polynomial (predicted landing value).
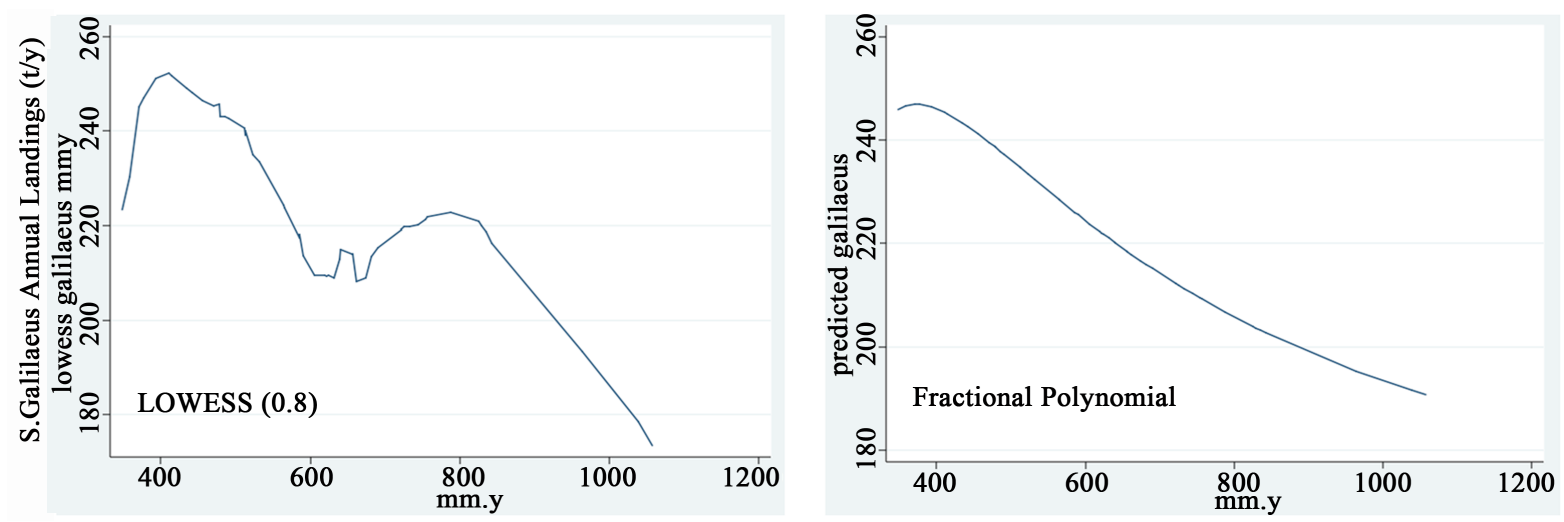

Figure 2. Annual landings (t/y) of S. galilaeus in Lake Kinneret Vs annual rain gauge (mm/y) given in two statistical analysis methods: LOWESS (trend of changes) and Fractional Polynomial (predicted landing value).

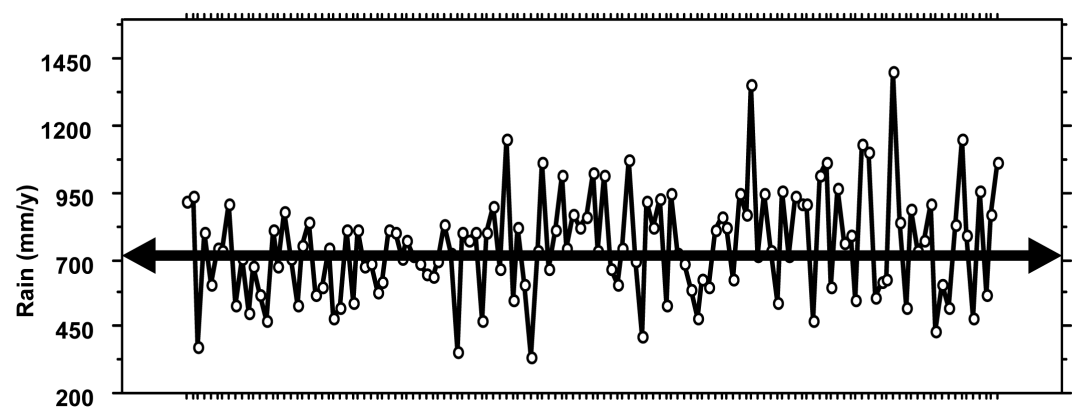

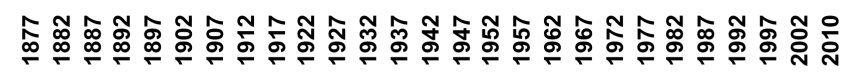

YEAR

Figure 3. Kfar Giladi annual rain gauge (mm/y): 1877-1929 synchronized with Berut Record; from 1929-measured. The multi-annual average $(752 \mathrm{~mm} / \mathrm{y})$ is arrowed. 
indicated (Figure 4). An indication of the ENSO effect, the deviations of annual values from the multi-annual average was calculated (Figure 5 and Figure 6): the frequency of high positive deviations (Figure 5) is prominent, and their relationship with ENSO cases is plotted in Figure 6. Heavy precipitation in the Kinneret Drainage Basin is fairly related to a WL increase in the lake during winter, when other withdrawals (pumping) are low. The precise record of the Kinneret WL started prior to 89 years ago (Figure 7), whilst several anthropogenic operations were carried out: South Dam and NCW constructions as well as the drainage of the Hula Valley (Figure 7). These activities did not confound the amplitude of the monthly winter fluctuations of WL (Figure 8). The regime of WL increase in winter months $(12,1$ - 4) was considered as an indication weather severity, where

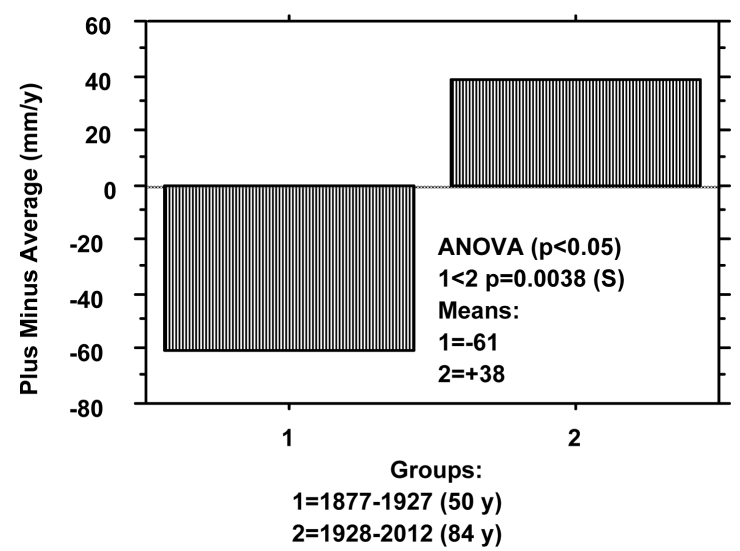

Figure 4. ANOVA test $(p<0.05)$ between two periods: $1=1877-1927,2=$ 1927-2012 and up and down deviations of rain gouge from multiannual average.

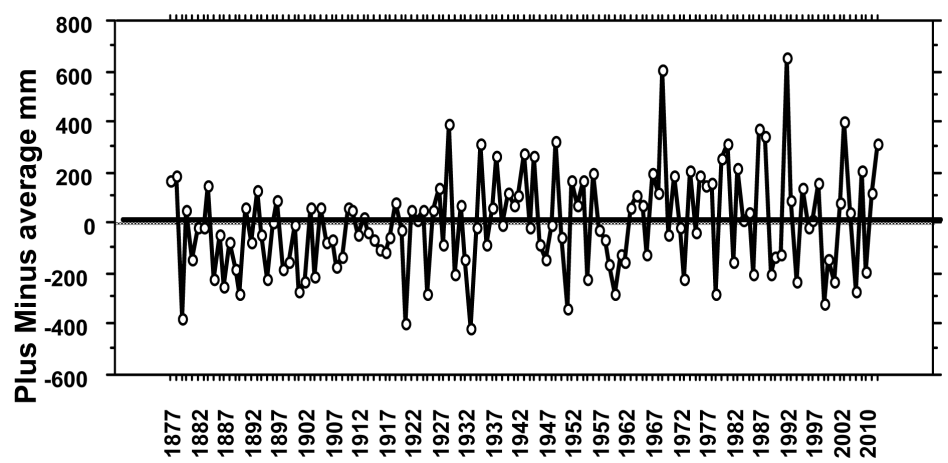

Figure 5. Kfar Giladi/Berut annual rain gauge (mm/y) above and below multiannual average.

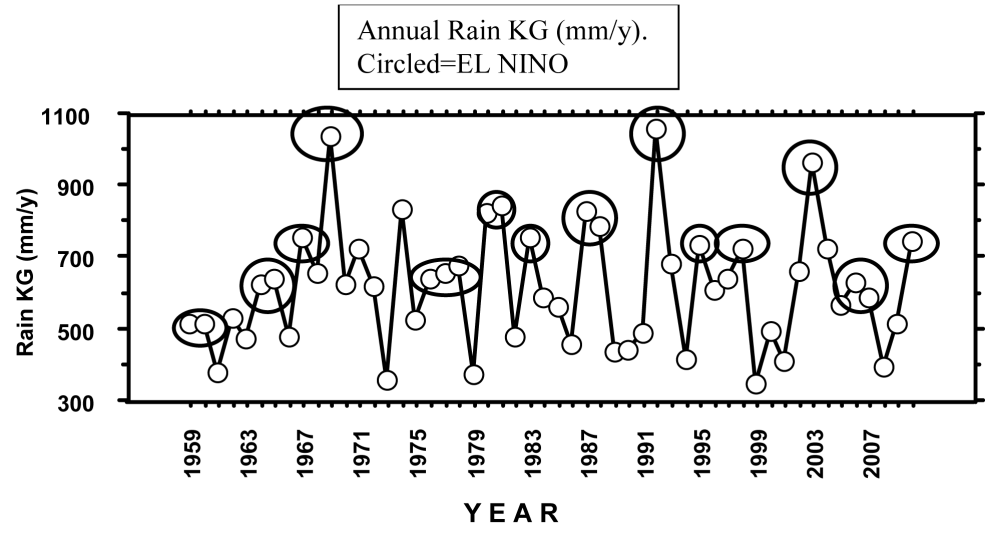

Figure 6. Annual rain gauge $(\mathrm{mm} / \mathrm{y})$ in Kfar Giladi station. 
high amplitudes were related to the ENSO effect (Figure 8). Another parameter which is Air temperature was also considered as a reflection of the ENSO conditions. In order to simplify the data evaluation, the usage of one daily value was adopted: the daily minimum. The record (1963-2014) of daily minimum was evaluated based on monthly and annual forms. The deviations of the annual means from the multi-annual average $\left(12.8^{\circ} \mathrm{C}\right)$ were considered as the conditions under ENSO (Figure 9). For the improvement of the analysis of the ENSO effect of SG reproduction dynamics, 6 "warm" and 6 "cold" representative years were selected from the entire record of Epilimnetic (surface-thermocline depth) mean temperatures [4] (Figure 10): the monthly averages of the "Warm" (1977, 1979, 1986, 1995, 1996, 1999) and the "Cold" (1980, 1983, 1989, 1990, 1992, 1993) are presented in Figure 10. Results indicate a shift of about one month, during the "Cold" regime, until suitable temperature $\left(>21^{\circ} \mathrm{C}\right)$ for reproduction was made available.

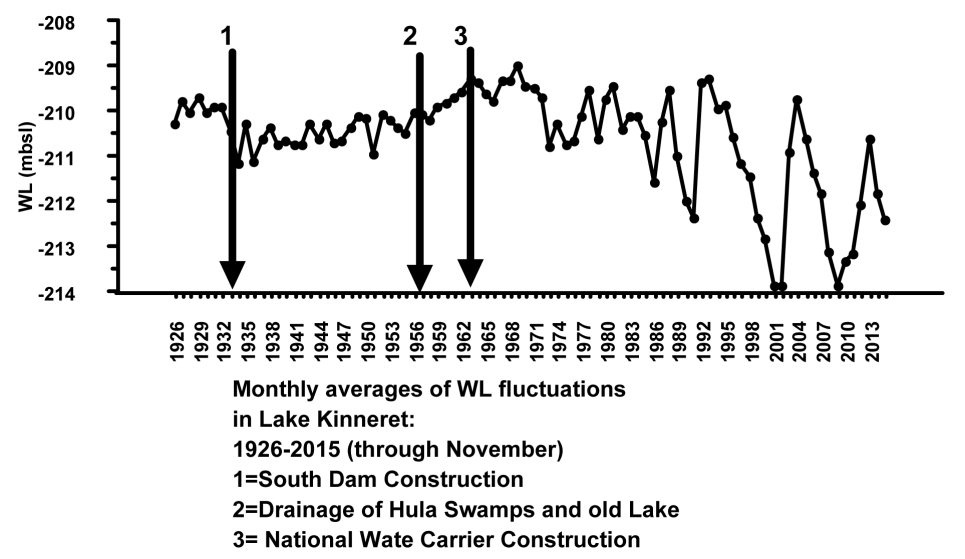

Figure 7. Monthly averages of Water Level (WL) fluctuations in Lake Kinneret (1926-2015) South Dam and National Water Carrier (NWC) constructions and, Hula Drainage are indicated.

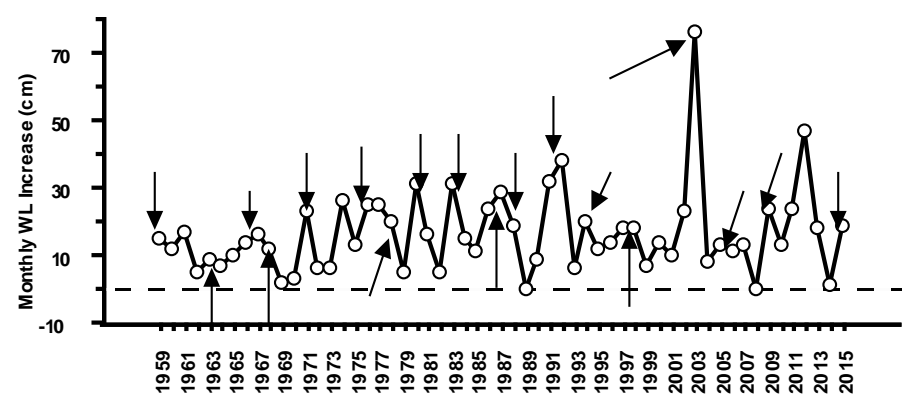

Figure 8. Winter month $(12,1,2,3)$ averages (1959-2015) of WL increase (cm/m) recorded ENSO events are arrowed.

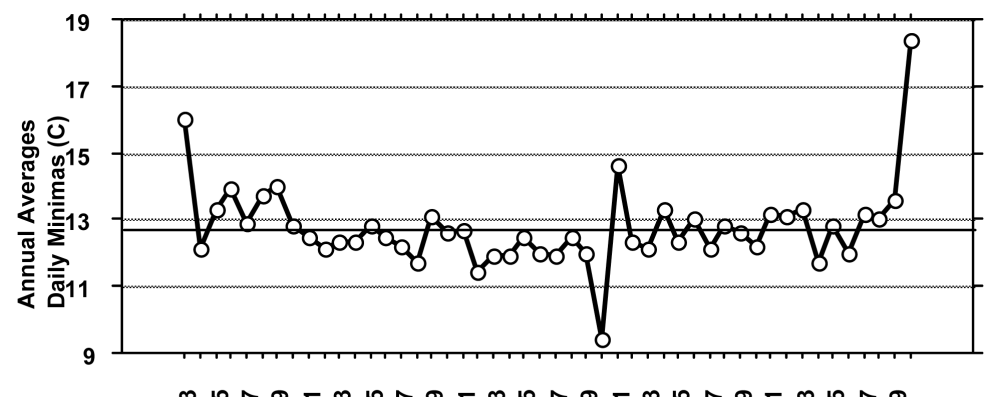

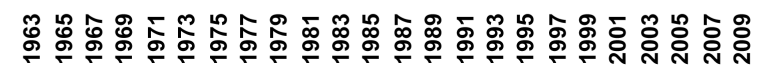

Figure 9. Annual (1963-2014) averages of daily air temperature minimum (2 m hight) $\left({ }^{\circ} \mathrm{C}\right)$, in Hula Valley (Dafna Station). Multi-annual average $\left(\mathbf{1 2 . 8}^{\circ} \mathbf{C}\right)$ is indicated. 


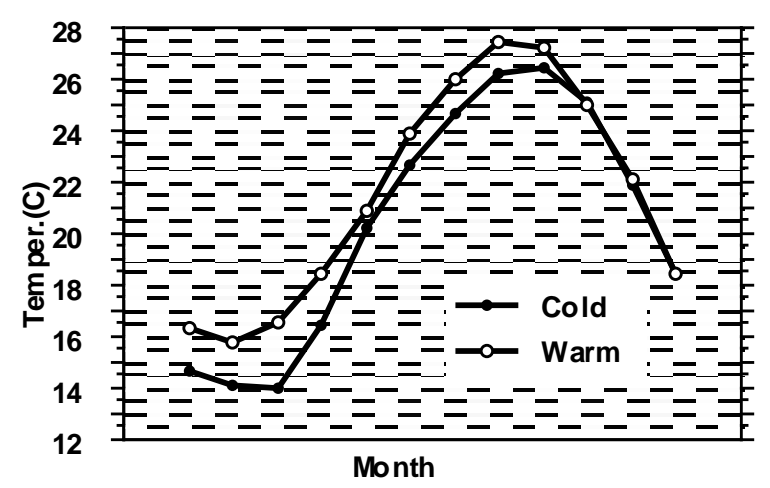

Figure 10. Monthly averages of epilimnetic temperatures: “cold” years: 1980, 1983, 1989, 1990, 1992, 1993; “warm” years: 1977, 1979, 1986, 1995, 1996, 1999.

\section{Discussion}

\subsection{The ENSO Event}

The strong connection existing between El-NIÑO and the Southern Oscillation (SO) Index has been identified since the year 1970, and titled as El-NIÑO/South Oscillation (ENSO) case. This event starts with a change in the Sea Surface Temperature (SST) in the Pacific Ocean, affecting the weather pattern at a great distance from the Pacific, such as the Mediterranean region, including Lake Kinneret and its drainage basin. Connections between SST in the Pacific Ocean (El NIÑO) and the climatic conditions in the Mediterranean region were found and documented [5] [8]-[12]. It was indicated that Israel gets an above average rainfall in winter, low temperatures and high velocity winds during El NIÑO years, and is below average in La Niña years [8] [9]. Nevertheless, a strong El NIÑO does not always result in the rainiest season, while an average El Niño can cause heavy flooding in Israel. It was suggested that the reason for the connection is the equator-ward migration of the polar jet stream (and hence, stormy tracks), during El NIÑO winters in the Mediterranean zone [8] [9] [12]. After the year 1976, there is a significant trend of higher frequencies, durations and intensities of El-Niño, relative to El-Niña. The cyclic pattern of ENSO events represents cycle frequencies of 2 - 7 years. Exceptional intensities of ENSO cases were recorded in the year 1982-83, 1997-98, 2009-10 and predicted for 2015-16. Data record of the Pacific SST and El-Niño development, respectively indicates several years with exceptionally low temperatures and a high precipitation in Israel, with a consequently high rate of Kinneret water level [8]. It was respectively corresponded with a decline in landings of SG, and enhancement of Bleaks population, surplus input of nutrients affecting water quality [13] [14].

\subsection{Fish Vulnerability to the Impact of ENSO}

The enigmatic relationship between ENSO events and fish population in Lake Kinneret give rise to curiosity. The zoogeographical origins of the Lake Kinneret fishes are Palaearctic (northern to Kinneret) and Ethiopian (southern to Kinneret). The Bleaks are Palaearctic and S. galilaeus, similar to the ecosystems through which other cichlids Ethiopian originated. The reproductive process is, therefore, different: Bleaks spawn in winter and reproduction efficiency, followed by an enhanced population increment is better succeeded, when precipitations are heavy during the longer winter time (November to April), accompanied by low temperatures and consequently, by a high rate of Water Level (WL) increase. The strong relationship existing between Bleaks larvae survivorship and a high rate of WL elevation ( $>2 \mathrm{~cm}$ per day), was previously documented [13] [14]. The optimal temperatures in late winter-spring time (April-July) for the reproduction of SG, are contradictorily higher: Reproduction activity begins, when the daily minimum of shallow waters $(<50 \mathrm{~cm})$ is above $21^{\circ} \mathrm{C}$. SG maintains 3 - 4 cycles of reproduction in African lakes [15] and therefore, a high severity of ENSO winter event conditions of longer duration of low temperatures in the shallows, a good number of SG reproduction start later. Ben-Tuvia [15] documented the reproductive season of SG from late March-Early April, until mid August. The result of the ENSO conditioned winter might be a shorter season of reproduction and the decline of spawning cycles, accompanied by smaller stock population size. Ben-Tuvia [15] indicates Temperature as the dominant factor controlling the length or duration of the spawning season. Spawning starts early and later, when Kinneret water 
temperatures are higher or lower, respectively. Conclusively, two contradictory developments arise during the ENSO event: 1) Heavy precipitations enhance WL increase and Bleak Fishes are proliferating, which is not favourable for both, fishery management (commercially unwanted) and water quality protection, zooplankton suppression and nano-planktonic algal biomass enhancement (Serruya et al. 1980); 2) The cold and longer winter condition bring about delay in SG spawning and consequently, make the duration of the reproductive season shorter, with a potential decline of population increment, which is not good for fishery management (valuable market fish) and for water quality protection (big sized algal species lower consumption) [16], that is, supporting SG fishery crisis. Other factors such as illegal fishing net meshes, Cormorant predation, lowering of stock, and of course, Bleaks food competition accelerated the natural cyclical decline, but a suggestion of recovery was previously predicted [17] [18]. Therefore, it is suggested that the major factor affecting reproduction efficiency of SG is neither food availability nor a submerged plant refuge for the fingerlings, but the availability of optimal temperatures. Due to technical difficulties, a long term record of temperatures in the shallows $(<50 \mathrm{~cm})$ is not available.

\subsection{ENSO and Fish Biology}

There are 27 fish species in Lake Kinneret, of which 8 are commercially exploited. Among the commercial species, Bleaks and SG are a key management component within the food web due to their market value (high and low), population density and influence on water quality. Bleaks are endemic, most abundant, but have the lowest market value, and SG is less abundant with the highest market value. Bleaks are zooplanktivore and SG is herbivore feeders. A major food component of Bleaks is zooplankton and that of SG are large cell phytoplanktonic algae. The impact of zooplanktivore fishes on water quality flows through the efficient consumption of small sized algae by zooplankton when those tiny plants control the water quality. The optimal fishery management is, therefore, due to reduced Bleaks' density and enhanced SG population. Consequent expected outcomes are: 1) Intensification of small algae consumption by zooplankton and 2) Consumption pressure on large cell algae by the commercially valuable SG [16]. It is suggested that the impact of ENSO works in opposite directions: the enhancement of Bleaks and a decline of SG. How do the same atmospheric conditions induce a contradiction effect on two fish species, inhabiting in one ecosystem? The answer lies in the origin of those two species: Bleaks originate from the northern and the cold Holoarctic globe zone while SG originates from the Ethiopian-Tropical southern region. The bleaks reproduce in winter and SG in summer. For the Bleaks reproduction, high regime winter rain conditions accompanied by the high river discharge, and the high rate of lake water level increase is optimal. On the contrary, for optimal reproduction of SG, high temperatures during the winter termination-spring-summer season are preferred. Long term heavy ENSO winter, accompanied by high rates of Lake Water Level increase, is optimal for Bleak proliferation, while the opposite is optimal for SG reproduction. SG is a mouth-breeder, and nest constructor in the shallows which start the reproduction, with a daily minimum of water temperature, not declining below $21^{\circ} \mathrm{C}$. The reproduction recruitment is related to the duration of time of the spawning period because the number of reproductive cycles is seasonally limited: low temperatures in spring time make it shorter. Long term winter period and low temperatures in early spring, delay the start of the process and result in a suitable and shorter summer period. Bleaks' reproduction occurs in winter and egg laying, accompanied by sperm fertilization occur in the open shallow waters, in sites with pebbles covered bottom. Fertilized eggs settled down at the bottom and must be immediately adhered to the bare pebbles' surface for incubation. If not adhered, the eggs quickly decompose and are covered by Fungus (Saprolegnia sp.). If the water level increases, at a rate below $2 \mathrm{~cm}$ per day, their surface is covered by settling particles and periphyton, (Bacteria, Algae, Protozoa, and so on.) and the adherence efficiency is low and thus, the eggs decompose. ENSO-heavy winter-Bleak reproduction, improved, and that of SG is a deteriorated-Bleak proliferation and SG decline, which initiate a lower quality of the Kinneret water.

It must be considered that several anthropogenic factors confound the sequence of events described here. Bleaks fishing was almost stopped during the 2000's, due to poor market conditions. The decline of SG was also strongly affected by the anthropogenic operations [1]. Nevertheless, the periodical population size of SG was highly affected by natural conditions, and ENSO is probably one of them. A quasi-cyclic fluctuations were documented by [17] [18] Pisanti (2005) indicated a decline in the landing of SG during the 2000's, but a close future recovery was predicted. Pisanti et al. [18] indicated cyclical landing frequencies. Pizanti [18] analyzed a dataset of annual (1935-2003) landings, and concluded periodical cycles $\left(r^{2}=0.344 ; p<0.01\right)$, with amplitude 
of three times difference between the minimal and maximal consecutive cyclical values. The impact of the confounded factors, on the periodical cycles of the SG population was eliminated, and three consecutive annual catches were averaged and plotted as 3 years running average line.

\section{Summary}

A sequence of reciprocal events was confirmed: ENSO, extreme weather conditions (precipitation, low air temperature, increase of water level) accompanied by enhancement of Bleak fishes and decline of SG in Lake Kinneret. It is suggested that ENSO has among other parameters an impact on the decline of SG and larger population size of Bleaks population and consequently affecting negatively the quality of water. It is likely that winter extreme in Kinneret region is a consequence of ENSO event and therefore negatively affecting Kinneret water quality.

\section{References}

[1] Gophen, M., Sonin, O., Lev, M. and Snovsky, G. (2015) Regulated Fishery is Beneficial for The Sustainability of Fish Populatio in Lake Kinneret (Israel). Open Journal of Ecology, 5, 513-527. http://dx.doi.org/10.4236/oje.2015.510042

[2] FDAM-Fishery Department Agriculture Ministry-Lake Kinneret Branch. Fisheries in Israel: Chapter: Lake Kinnere, 1970-2013.

[3] Walline, P. and KLL-Kinneret Limnlogical Laboratory-IOLR. Annual Reports. Chapter: Fish Distribution, Acoustic Survey. 1987-2005.

[4] KLL-IOLR LKDB Annual Reports, 1970-2013.

[5] Climate Prediction Center-Monitoring and Data: ENSO-Previous Events. EL-El-Niño/Southern Oscillation (ENSO), Historical EL-El-Niño/La-Niña. 2015. http://www.CPC.NOAA.gov

[6] IMS-Israeli Meteorological Service. Annual Reports, 1929-2012.

[7] STATA 9.1 Statistics/Data Analysis, 1984-2005. College Station, Texas, USA.

[8] Price, C., Stone, L., Huppert, A., Rajagopalan, B. and Alpert, P. (1998) A Possible Link between EL-NIÑO and Precipitation in Israel. Geophysical Research Letters, 25, 3963-3966.

[9] Alpert, P. and Reisin, T. (1986) An Early Winter Polar Air Mass Penetration to the Eastern Mediterranean; American Meteorological Society, Notes and Correspondence. Monthly Weather Review, 114, 1411-1418. http://dx.doi.org/10.1175/1520-0493(1986)114<1411:AEWPAM>2.0.CO;2

[10] Ttrenberth, K.E. and Hoar, T.J. (1997) El-Nino and Climate Change. Geophysical Research Letters, 24, 3057-3060. http://dx.doi.org/10.1029/97GL03092

[11] Wuethrich, B. (1995) El-Niño Goes Critical. New Scientist, 4, 32-35.

[12] Rajagopalan, B.U. and Cane, M.A. (1997) Anomalous ENSO Occurrence: An Alternate View. Journal of Climate, 10, 235-2357. http://dx.doi.org/10.1175/1520-0442(1997)010<2351:AEOAAV>2.0.CO;2

[13] Gophen, M. (2004) Hydrology and Management of Lake Kinneret Aimed at Water Quality Protection. In: Zreiny, F. and Jaeschke, W., Eds., Water in the Middle East and in North Africa: Resources, Protection, and Management, Springer-Verlag, Berlin, 207-226. http://dx.doi.org/10.1007/978-3-662-10866-6 18

[14] Gophen, M. (2004) Ecohydrological Management of Lake Kinneret: A Case Study. Ecohydrology and Hydrobiology, 4, 397-408.

[15] FAO (1974) Synopsis of Biological Data on Sarotherodon galilaeus. Chapter 3: Reproduction, Johnson, R.P., Ed., No. 90, 1-15.

[16] Serruya, C., Gophen, M. and Pollingher, U. (1980) Lake Kinneret: Carbon Flow Patterns and Ecosystem Management. Archiv fur Hydrobiologie, 88, 265-302.

[17] Pisanti, S., Ben-Yami, M. and Talpaz, H. (1987) Quasi-Fluctuation in St. Peter’s Fish in Lake Kinneret and Their Management Implications A: The Cyclic and the Effect of Effort. Fisheries and Fish Breeding in Israel, 20, 26-38. (In Hebrew, English Abstract)

[18] Pisanti, S. (2005) Quasi-Cyclic Fluctuations in St. Peter's Fish Landings in Lake Kinneret-Continues. Fisheries and Fish Breeding in Israel, 1, 777-781. (In Hebrew, English Abstract) 